\title{
Maternity in adolescents and its association with caesarean labor
}

\author{
Henry Rodrigo Gallardo-Lizarazo* \\ Ingrid Sofía Guerrero-Romero** \\ Jorge Ernesto Niño-González*** \\ Mariana Villaveces-Franco ${ }^{* * * *}$
}

Objective: to evaluate the association between adolescence and cesarean section in women aged 10-19 years compared with those found in ages between 19 and 25 years, patients in a hospital, and determine its association with sociodemographic variables and neonatal in terms of prematurity, and Apgar low birth weight. Materials and Methods: a case-control study was performed using a simple random sampling, considering the calculation of a statistical sample. a total of 1,304 cases and 2,608 controls were included. First time mom patients treated at an institution $\mathrm{x}$ over a period of three years, to determine associations of risk through analysis of hypothesis testing is included. Results: the risk of caesarean section in teenagers is (OR 1.13, 95\% CI 1.10 to 1.51). In addition, it was determined that there is an increased risk of low birth weight (OR 9.4, 95\% CI 7.59 to 11.76), with no difference in adolescents in the risk of Apgar down score at minute and 5 minutes later. Conclusion: there is an increased risk of low birth weight and require termination of pregnancy via cesarean in adolescents compared to young adults, especially if they are under 14. It is necessary to promote campaigns to prevent teenage pregnancy, as the main measure of control over these population.

KEYWORDS: abdominal delivery, childbirth, complications of pregnancy, teenage pregnancy, teenagers ${ }^{* * * *}$. 



\section{Mãe adolescente e sua associação com cesariana}

\section{SUMÁRIO}

Objetivo: avaliar a associação entre a adolescência ea cesariana em mulheres com idade entre 10 a 19 anos, em comparação com aqueles encontrados na faixa etária entre 19 e 25 anos, servido em um hospital, e determinar associação STI com variáveis neonatais e sociodemográficos em termos de prematuridade, Apgar e baixo peso ao nascer. Materiais e Métodos: um estudo de caso-controle foi realizado utilizando amostragem aleatória simples, Considerando o cálculo de uma amostra estatística. Um total de 1.304 casos e 2.608 controles foram incluídos. Primigestas pacientes tratados em uma instituição $\mathrm{x}$ ao longo de um período de três anos, para determinar associações de risco através da análise dos testes de hipóteses está incluído. Resultados: o risco de cesariana em adolescentes é (ou CI 1,13, 95\% 1,10-1,51). Além disso, determinou-se que há um aumento do risco de baixo peso ao nascer (OR 9,4, IC 95\% 7,59-11,76), não havendo diferença em adolescentes no risco de baixo índice de Apgar no minuto 5 minutos. Conclusão: há um aumento do risco de baixo peso ao nascer e exigem a interrupção da gravidez através de cesariana em adolescentes em comparação com adultos jovens, especialmente se eles estão sob 14 . É necessário promover campanhas de prevenção da gravidez na adolescência, como a principal medida de controle sobre a população.

PALAVRAS-CHAVE: parto abdominal, parto, complicações da gravidez, gravidez na adolescencia, adolescentes. 
ISSN 1794-9831

E-ISSN 2322-7028

Vol. 12 No. 2

Jul - Dic 2015

Cúcuta, Colombia

\section{INTRODUCTION}

The presence of teenage pregnancy in women under 19 years is considered a complex public health problem which involves a fail in the family, education and society in general (1); therefore, it is considered a condition that by itself carries greater tendencies to show adverse effects, such results as increased maternal mortality, higher prevalence of endometritis, increased incidence of anemia, postpartum hemorrhage, need for cesarean section, instrumental delivery, hypertensive disorders, among others (1).

These complications, added to the very biological immaturity of age, lack of planning in achieving a pregnancy, inadequate access to prenatal care, poor nutrition of mother and maternal stress (2) all of them, make a worse outlook and they are one risk condition for this population.

Teen pregnancy has not only associated with higher maternal complications; also described adverse neonatal outcomes such as preterm delivery, low birth weight, need for admission to the neonatal care, genetic abnormalities and increased death rates in postnatal life (3). It has even been reported that the children of these women are put in danger in many cases to be victims of physical or sexual abuse, and present major problems in their behavior in adulthood (4), which affects teen pregnancy as a condition with long-term effects.

Annually, $11 \%$ of global births occur in adolescents between 15 and 19 years, with a fertility rate estimated worldwide, for the period from 2000 to 2005, from 55.3 per 1000 people, which means an average of $5.5 \%$ of adolescent births each year and about 13 million children of teenage mothers (5-6).

Its incidence worldwide and presentation is very divergent and variable among regions, with a range that goes from $2 \%$ in China to $18 \%$ in Latin America and the Caribbean (7). Half of these births occur mainly in countries like Bangladesh, Brazil, Republic of Congo, Ethiopia, Nigeria, India and the United States (7), which means that about $95 \%$ of these births occur in developing countries $(1,6)$.

In Colombia, the situation is also alarming because according to the National Demographic and Health survey conducted by Profamilia in 2010 (8), the fertility rate in women under 20 years is between 70 and 90 per thousand; although these values have declined over the past 20 years, the reproductive behavior of this population still is a major concern (9).

However, the role of maternal age on adverse outcomes, maternal and neonatal seems that is still not well established. Recent studies show that obstetric and fetal outcomes are not affected by maternal age, and may even be similar between the two groups, with no statistically significant difference $(2,6)$; it hasn't been shown that caesarean section rates are higher in adolescents compared to adults $(2-3,10)$.

The high rate of teenage pregnancies in the population looked after by the institution, joined to the little information performed by studies, the wide variation in results with respect to the birth canal, the high number of caesarean sections, high rates of maternity in adolescents and negative effects on social, family and economic level (10), are factors that allow to carry out a study to determine the frequency of caesarean in first time pregnant girls between 10 and 19 years, compared with young adults between 19 and 25 years

In addition, it aims to determine the factors associated with taking into account maternal age as the main risk factor, and to evaluate if there are greater tendencies to present low birth weight, low Apgar values and neonatal prematurity versus young adults between 19 and 25 years.

\section{MATERIALS AND METHODS}

A study of cases and controls and data collection was done retrospectively. The entire population of first time pregnant girls between 10 and 25 were evaluated, who went to the hospital, in order to obtain medical care and / or labor, from January 1st ,2011 to December 31st , 2013. The selected cases evaluated were the first time pregnant girls with caesarean section, and controls, patients pregnancy ended in vaginal birth.

Maternal age factor was evaluated, with a corelation 1: 2 and a simple random sampling considering calculating a statistical sample and a list of random numbers selected by the MS Excel statistical program was run. 
To calculate the sample the stat calc program by Epi Info CDC was used, throught Fleiss formula for independent groups, following the pattern of normality with a reliability of $95 \%$ and $80 \%$ power. In total 8, 977 milk mother's, and the sample size, estimated at 1,304 cases and 2,608 controls defined. Losses were assumed by incomplete information and these values increased by $20 \%$ each one.

The inclusion criteria used were the first time pregnant women admitted to the institution, aged 10 and 25 years, who finished their gestation in the time period. In the same way, those patients who had incompleted data and who requested their voluntary departure departaure and / or were referred, patients had no viable pregnancies (less than 24 weeks gestation) or submit other unrelated comorbidities with age that may overestimatee proportion of caesarean sections, such as the presence of autoimmune diseases, history of diabetes mellitus, and renal or cardiovascular disease diagnosed before pregnancy.

The data were taken from two major information systems, the RUAF (Single Registry of Members of Births and Deaths), which is a mandatory document to apply nationally and HEON system (Health On Line SA), software for storing all the medical records of patients treated at the institution.

A characterization of the population regarding the path end gestation, maternal age and the main neonatal outcomes in terms of prematurity, weight and neonatal Apgar at one and 5 minutes was performed. Education, marital status, ethnicity, area of residence, number of prenatal visits, multiple pregnancy and newborn gender. Additionally, other socio-demographic data as obtained.

A bivariate analysis was performed to compare the two groups -adolescentes 10 to 19 years and young adult women ages 19 to 25 years with all possible influential factors and contingency tables were set $2 \mathrm{x}$ 2. In evaluating variables qualitative and considering the population was parametric, the statistical analysis was done by chi square test; if the population was nonparametric Mann U test was used Whiteney with their respective calculations of OR and confidence intervals of $95 \%$.

Statistically significant differences for an alpha error of $5 \%$ and $20 \%$ beta error program. For data analysis the initial tabulation of data was performed in Microsoft Excel software, with subsequent extrapolation of them to SPSS for Windows software for analysis Statistical (Software Military University) and Stata program for calculation.

It was verified its compliance with Resolution No. 008430 of 1993 (11), they are stablished the scientific, technical and administrative rules for health research standards. It is considered a study without risk, since the techniques and methods used research are retrospective and documentary, in which no intentional intervention is performed, using for this purpose only the review of medical records and consolidated institutional deliveries.

In the same way, it was met with Article 6, paragraph $\mathrm{F}$, of the same resolution (11), which specifies that the research was conducted by skilled health certificated people for the exercise of the medical profession by the competent authorities and needed knowledge in the area to be concerned.

According to data, the strict principle of confidentiality was maintained, since no information that would allow the identification of patients was obtained; on the other hand, the only ones who had access to data and advisers were the authors of this work, storage of information in databases created in the institution during the study.

Regarding informed consent, Article 16, paragraph I of Resolution No. 0084301993 (11), which stipulates that "in the case of an investigation without risk, it may exempt the researcher from obtaining is abided thereof".

This research was conducted under the supervision and approval of teachers Unit of Gynecology and Obstetrics of the hospital case of study, and with the authorization of the Medical Ethics Committee of the institution.

\section{OBJECTIVES}

\section{General purpose}

To evaluate the association between adolescence and cesarean section in first time pregnant adolescents (10-19 years) compared to young adult women (19 to 25 ) in a period of three years and determine its association with sociodemographic variables in terms
ISSN 1794-9831

E-ISSN 2322-7028

Vol. 12 No. 2

Jul - Dic 2015

Cúcuta, Colombia 

Maternity in adolescents and its association with caesarean labor - Henry Rodrigo Gallardo-Lizarazo, Ingrid Sofía Guerrero-Romero, Jorge Ernesto Niño-González, Mariana Villaveces-Franco

Table1. Characteristics of the population.

\begin{tabular}{|c|c|c|c|c|}
\hline Variable & Characteristics & $\begin{array}{l}\text { Teenagers } \\
\operatorname{group}(n=1.304)\end{array}$ & $\begin{array}{l}\begin{array}{l}\text { Young adults } \\
(\mathrm{n}=2.608)\end{array} \\
\end{array}$ & $\mathbf{P}^{*}$ \\
\hline Maternal age & $\begin{array}{l}\text { Average DE } \\
\text { RIC 25-75 } \\
\text { Mín.-máx. }\end{array}$ & $\begin{array}{l}16,8 \text { DE } 1,26 \\
16-18 \\
12-18\end{array}$ & $\begin{array}{l}\text { 21,5 DE 1,94 } \\
19-24 \\
19-25\end{array}$ & 0,001 \\
\hline Marital status & $\begin{array}{l}\text { Single } \\
\text { No married/living with her } \\
\text { husband for more than two } \\
\text { years } \\
\text { Living together } \\
\text { Married } \\
\text { Separated/divorced } \\
\text { Widow } \\
\text { Non data }\end{array}$ & $\begin{array}{l}49,54(633) \\
33,36(435) \\
\\
15,95(208) \\
1,69(22) \\
0,00(0) \\
0,08(1) \\
0,38(5)\end{array}$ & $\begin{array}{l}26,07(680) \\
31,48(821) \\
\\
33,63(877) \\
8,61(213) \\
0,19(5) \\
0,23(6) \\
0,23(6)\end{array}$ & 0,06 \\
\hline $\begin{array}{l}\text { Academic } \\
\text { studies }\end{array}$ & $\begin{array}{l}\text { No studies } \\
\text { Primary school } \\
\text { Secondary school } \\
\text { High school } \\
\text { College } \\
\text { Technologic studies } \\
\text { Professional studies } \\
\text { Postgraduate studies }\end{array}$ & $\begin{array}{l}0,00(0) \\
8,82(115) \\
44,94(586) \\
3,60(47) \\
39,34(513) \\
2,43(33) \\
0,69(9) \\
0,00(0)\end{array}$ & $\begin{array}{l}0,03(1) \\
2,33(61) \\
17,29(451) \\
6,55(171) \\
45,36(1.183) \\
28,05(733) \\
0,76(2) \\
0,23(6)\end{array}$ & 0,42 \\
\hline Etnicity & $\begin{array}{l}\text { Black, african origin } \\
\text { Mestizo } \\
\text { Indigenous }\end{array}$ & $\begin{array}{l}0,23(3) \\
99,77(1.301) \\
0,00(0)\end{array}$ & $\begin{array}{l}0,26(7) \\
99,73(2.601) \\
0,00(0)\end{array}$ & 0,88 \\
\hline Residence area & $\begin{array}{l}\text { Town } \\
\text { City } \\
\text { Country }\end{array}$ & $\begin{array}{l}99,4(1.296) \\
0,07(1) \\
0,53(7)\end{array}$ & $\begin{array}{l}99,88(2.605) \\
0,11(3) \\
0,00(0)\end{array}$ & 0,91 \\
\hline Gestational Age & $\begin{array}{l}\text { Average } \\
\text { RIC 25-75 } \\
\text { Min.-max. }\end{array}$ & $\begin{array}{l}37,17 \text { DE } 1,93 \\
37,5-39,5 \\
26-42\end{array}$ & $\begin{array}{l}38,15 \text { DE } 2,2 \\
36,5-39,5 \\
25-41\end{array}$ & 0,77 \\
\hline $\begin{array}{l}\text { Number of care } \\
\text { appointments }\end{array}$ & $\begin{array}{l}\text { Non appointment } \\
4 \text { or less } \\
\text { More than } 4\end{array}$ & $\begin{array}{l}1,07(14) \\
16,41(214) \\
85,52(1.076)\end{array}$ & $\begin{array}{l}0,46(13) \\
12,85(335) \\
86,69(2.260)\end{array}$ & 0,74 \\
\hline Multiciplity & $\begin{array}{l}\text { Simple } \\
\text { Multiple }\end{array}$ & $\begin{array}{l}99,62(1.299) \\
0,38(5)\end{array}$ & $\begin{array}{l}99,65(2.599) \\
0,35(9)\end{array}$ & 0,21 \\
\hline Rh factor & Negative & $3,52(46)$ & $4,89(125)$ & 0,11 \\
\hline
\end{tabular}

Source: RUAF - HEON, 2015. 
ISSN 1794-9831

E-ISSN 2322-7028

Vol. 12 No. 2

Jul - Dic 2015

Cúcuta, Colombia
The average gestational age in adolescents was 37.1 weeks (26-42 weeks), and young adults, 38.1 weeks (25-41 weeks). 99\% of pregnancies were single pregnancies. In total, $85.5 \%$ of adolescents and $86.6 \%$ of young adults attended more than four prenatal visits.

Path termination of pregnancy and indications of cesarean section

The way of completion of the most common pregnancy in adolescent and adult population was vaginal delivery (63.80 vs. $56.86 \%$ ), followed by caesarean section (32.8 vs. $36.9 \%$ ) and less frequently instumental childbirth (3.37 vs. $3.95 \%$ ).

The main indications for cesarean section, both adolescents and young adults were the following causes: Obstetric (Bishop unfavorable detention dilation, cephalopelvic disproportion), by $46 \%$, followed by the mother, in a 30\% (hypertensive disorders, anemia, maternal conditions limiting vaginal delivery) and a lower percentage fetal (malformations, macrosomia, intrauterine growth restriction, fetal been unsatisfactory, prematurity) corresponding to $24 \%$ of the total (see figure 1).

Figure 1. Relationship of cesarean section indications by groups of the population under study.

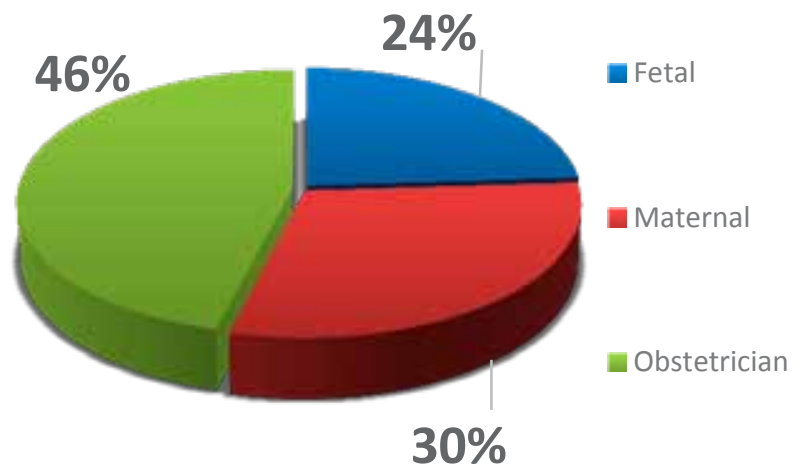

Source: RUAF - HEON, 2015.

The indications for which they decided to terminate pregnancy via cesarean section were: arrest dilation and / or descent, $13.8 \%$ (200 cases), followed by cephalopelvic disproportion, $11.5 \%$ (168 cases); fetal unsatisfactory state, $7.4 \%$ (108 cases); mild and severe preeclampsia, $5.0 \%$ (73 cases); unfavorable bishop, $4.3 \%$ (63 cases), and failed induction, 3.7\% (54 cases).

By subdividing the adolescents according to age subgroups proposed by the World Health Organization (WHO), the following was found: $2.3 \%$ of the patients were between 10 to 14 years and $97.6 \%$ among 15 and $18.85 \%$ of the cases were pregnancy to term; of these patients, $56.6 \%$ completed their gestation by vaginal or instrumental delivery and caesarean $43.3 \%$.
The indications for cesarean section in primigravidae adolescents between 10 and 14 years were: cephalopelvic disproportion, $33 \%$; detention dilation, $10 \%$; severe preeclampsia, $6.6 \%$; gestational syphilis, $3.3 \%$; failed induction, $3.3 \%$; slow fetal growth, $3.3 \%$; and other causes $36.6 \%$.

Talking about patients in late adolescence (15 to 18 years), it was observed that pregnancy ended vaginally or instrumented in $67.42 \%$ of cases, and cesarean section in $32.57 \%$. The indications for cesarean section in this group were: detention in dilation job, 30.8\%; cephalopelvic disproportion $21.6 \%$; intrauterine growth restriction (IUGR), 8.6\%; fetal unsatisfactory state, $7.7 \%$; failed induction, $7.2 \%$; preeclampsia, $7.2 \%$ and other indications, $16.6 \%$. 
In the young adult population pathway completion of pregnancy or vaginal delivery was implemented in $68.8 \%$ of cases. As for caesarean section, it was noted that this procedure was performed in $39.18 \%$ of young adults, which corresponds to $70.4 \%$ of all caesarean delivery in the period studied.

Comparing caesarean section rates among different age subgroups, statistically significant differences among adolescents aged 10 to 14 years were discovered vs. late adolescents between 15 and 19 years old and young adults between 19 and 25 years.
In the first, the caesarean section rate was $43.3 \%$, compared with $32.5 \%$ for those between 15 and 19 years and $39.18 \%$ in young adults between 19 and 25 years (p 0.01), as it is shown in table 2 .

After performing the bivariate analysis through hypothesis testing, taking into account age (adolescents vs. young adults), it corroborated the existence of a higher risk of ending in caesarean as a teenager (OR 1.3, 95\% CI 114 to 1.51 ), with statistically significant results (p 0.000001) as shown in table 2.

Table 2. Age groups according to WHO.

\begin{tabular}{|c|c|c|c|c|c|c|}
\hline & \multicolumn{2}{|c|}{$\begin{array}{l}\text { Early adolescence } \\
\text { 10-14 years old } \\
N=30\end{array}$} & \multicolumn{2}{|c|}{$\begin{array}{l}\text { Late adolescence } \\
\text { 15-18 years old } \\
\mathrm{N}=1.274\end{array}$} & \multicolumn{2}{|c|}{$\begin{array}{l}\text { Early adulthood } \\
\text { 19-25 years old } \\
\mathrm{N}=\mathbf{2 . 6 0 8}\end{array}$} \\
\hline & $\mathrm{N}$ & $\%$ & $\mathrm{~N}$ & $\%$ & $\mathrm{~N}$ & $\%$ \\
\hline $\begin{array}{l}\text { Vaginal } \\
\text { delivery and / } \\
\text { or } \\
\text { instrumented }\end{array}$ & 17 & 56,6 & 859 & 67,42 & 1.586 & 60,81 \\
\hline Cesarean & 13 & 43,3 & 415 & 32,57 & 1.022 & 39,18 \\
\hline
\end{tabular}

Source: RUAF - HEON, 2015.

\section{Neonatal features}

The average birth weight of children / as adolescent patients was 2,904 g vs. 2,919 $\mathrm{g}$ in the children / as young adult patients ( $\mathrm{p} 0.54)$. The average size was $48.6 \mathrm{~cm}$ in cases and $48.6 \mathrm{~cm}$ in controls (p 0.56).

Only $16.7 \%$ of children / as adolescent patients had a birth weight less than $2,500 \mathrm{~g}$, with an equivalent rate of $16.02 \%$ young adults. In relation to prematurity, low frequency of extreme preterm births was observed: $0.38 \%$ in the group of adolescent and $0.61 \%$ for young adults; to analyze the frequency of preterm labor (between 28 and 36 weeks), a frequency of
$12.3 \%$ for girls and $12.5 \%$ for young adults (p 0.33 ) it found no statistically significant difference between both.

About the Apgar score at birth, the average at 5 minutes was 9.03 in the children / as teenage mothers vs. 8,99 in the children / as young adult mothers, with no statistically significant difference between both groups ( $p$ 0.47). Upon bivariate analysis through hypothesis testing, it was found that maternal age is not a risk factor for low birth Apgar score at one minute ( $p 0.31$ ) or 5 minutes (p 0.47). It is show in table 3 and 4.
ISSN 1794-9831

E-ISSN 2322-7028

Vol. 12 No. 2

Jul - Dic 2015

Cúcuta, Colombia 
Table 3. Frequency of neonatal outcomes according to maternal age.

\begin{tabular}{|c|c|c|c|c|}
\hline Variables & Features & $\begin{array}{c}\text { Teenager } \\
1.304\end{array}$ & $\begin{array}{c}\text { Adult teenagers } \\
\mathbf{2 . 6 0 8}\end{array}$ & $P^{*}$ \\
\hline New born gender & $\begin{array}{l}\text { Female } \\
\text { Male }\end{array}$ & $\begin{array}{l}46,32(604) \\
53,68(700)\end{array}$ & $\begin{array}{l}48,70(1.270) \\
51,30(1.338)\end{array}$ & 0,48 \\
\hline Weight & $\begin{array}{l}\text { Average and DE } \\
\text { RIC 25-75 } \\
\text { Min.-max }\end{array}$ & $\begin{array}{l}2.904 \mathrm{DE} 477 \mathrm{~g} \\
2.645-3.198 \\
610-4.119\end{array}$ & $\begin{array}{l}2.919 \text { DE } 500 \\
2.673-3.236 \\
500-4.794\end{array}$ & 0,83 \\
\hline Gestational period & $\begin{array}{l}\text { Preterm } \\
\text { Preterm }(28-36) \\
\text { term }(37-40) \\
\text { Posterm }(>40)\end{array}$ & $\begin{array}{l}0,38(5) \\
12,35(106) \\
86,04(1.122) \\
1,23(16)\end{array}$ & $\begin{array}{l}0,61(16) \\
12,50(326) \\
85,63(2.234) \\
1,19(32)\end{array}$ & 0,33 \\
\hline $\begin{array}{l}\text { Apgar neonatal to } \\
\text { the minute }\end{array}$ & $\begin{array}{l}\text { Average } \\
\text { Min.-max. }\end{array}$ & $\begin{array}{l}7,85 \\
1-10\end{array}$ & $\begin{array}{l}7,82 \\
1-10\end{array}$ & 0,43 \\
\hline $\begin{array}{l}\text { Apgar neonatal to } \\
\text { five minutes }\end{array}$ & $\begin{array}{l}\text { Average } \\
\text { Min.-max. }\end{array}$ & $\begin{array}{l}9,03 \\
1-10\end{array}$ & $\begin{array}{l}8,99 \\
1-10\end{array}$ & 0,41 \\
\hline Low birth weight & $\begin{array}{l}\text { less than } 2500 \mathrm{~g} \text { and } \\
\text { greater than } 2500 \mathrm{~g}\end{array}$ & $\begin{array}{l}16,7(219) \\
83,2(1.085)\end{array}$ & $\begin{array}{l}16,02(418) \\
83,97(2.190)\end{array}$ & 0,57 \\
\hline
\end{tabular}

* Normality test of Shapiro Wilks.

Source: RUAF - HEON, 2015

Table 4. Bivariate analysis using hypothesis testing.

\begin{tabular}{|l|l|l|}
\hline & Adolescents vs. Young adolescents & $P^{*}$ \\
\hline F gender vs. M gender & OR 0,10, IC 95\% 0,79-1,03 & 0,16 \\
\hline Low weight & OR 9,4, IC 95\% 7,59-11,76 & 0,00 \\
\hline Apgar under minute & OR 1,16, IC 95\% 0,86-14,5 & 0,31 \\
\hline Apgar under five minutes & OR 2,3, IC 95\% 0,64-16,2 & 0,47 \\
\hline Cesarean & & 0,0000 \\
\hline
\end{tabular}

* Testing hypotheses using chi square.

Source: RUAF - HEON, 2015.

In relation to the presentation of low birth weight, a frequency of $16.7 \%$ was found in the group of cases vs. $16.02 \%$ in controls ( $p$ 0.57). According to the age with the different variables and make the bivariate analysis through hypothesis testing, it was found that the children of adolescents have an increased risk of low birth weight, compared with young adult (OR 9.4, $95 \%$ CI 7.59 to 11.76 ), with statistically significant difference, as shown in table 4.

\section{DISCUSSION}

\section{General features}

Teen pregnancy, pregnancy defined as occurring in women between 10 and 19 years, is considered a public health problem that has traditionally been qualified as high-risk condition, due to its association with adverse outcomes for both the mother and the infant (12). They are well known negative effects on 
the health of mother and child and their implications biopsychosocial level; include the perpetuation of the cycle of poverty, the difficulties in achieving higher levels of education, disruption of the family unit and the presence of subsequent pregnancies, among others (13-14).

An estimated 750,000 teenagers become pregnant each year, including pregnancies ending in live births, induced abortions and miscarriages (6). According to WHO reports (7), about 16 million girls between 15 and 19 years end their pregnancy to term born alive, implying that adolescents accounted for $11 \%$ of births in the world.

However, global statistics reported between 1990 and 2004 showed that teen pregnancy rates have decreased from 116.8 per 1,000 to 72.2 per 1,000 , with an estimated global reduction of $38 \%(7)$.

In Colombia, according to the National Demographic and Health conducted by Profamilia (8) in 2010, it showed that about $16 \%$ of Colombian adolescents are already mothers, and $4 \%$ of them are expecting their first child (9), with a fertility rate in women under 20 years of $70-90$ per thousand; these data suggest a stabilization compared with previously reported between 1990 and 2005, which no longer a problem in the national context.

Have proposed several reasons why adolescents are at risk for pregnancy at a very young age, including early pubertal development, early initiation of sex, ignorance in the use of contraception, sex does not consensual, personal history of sexual abuse in childhood and other sociodemographic reasons, such as low education, poor school performance, family dysfunction, among others (15).

In addition to the increase in the number of teenage pregnancies, the next problem to be addressed is the increased incidence of caesarean sections, which has also become a major problem for public health worldwide. In the last three decades, Caesarean births have increased dramatically, especially in developing countries like Brazil, with caesarean rates to $36.4 \%$, compared with other developed countries, with rates below $15 \%$ (1). In Colombia, the picture is also worrisome, with rates ranging between 25 and $30 \%$ (8).
Regarding the cesarean section in adolescents, it is known that they are more likely to require this intervention, especially to present failures in the progression of the second stage of labor and immaturity of the pelvis, with the secondary increase in the presentation dystocia and cephalopelvic disproportion; however, the indication for performing routine is still not well studied, and there are limited data that cast doubt on this information (16-17).

\section{Population characteristics}

In the hospital under study, 8,977 patients were treated primigravidae over a period of three years and a total of 1,304 adolescents (average age 16.8 years) and 2,608 adults (average 21.5 years) were analyzed.

On the marital status of adolescent girls, the results showed that $49.31 \%$ live in free union, which is not surprising, because as evidenced by the study of Gomez and Montoya (14), conducted in a population in Medellin, Colombia, living with the couple has been associated with increased desire to have children, as well as increased risk (16.47 times) to get pregnant; this situation can be explained by dysfunction of the primary household and desire of the adolescent to form a new home (15).

Analizing the the level of schooling, it was observed that most adolescents were attending junior high school (44.9\%) and academic average (39.34\%), and none of them was reported to be illiterate. In the case of young adults, most of them were in high school or middle school academic $(62.65 \%)$, data matching with the National Demographic and Health Survey 2010 (8), which showed that $76 \%$ of women in Colombia have some level of secondary or higher education, and that the country, for 2010 , only $2 \%$ of women between 15 and 49 years had no academic studies (8).

\section{Teenage motherhood and her relationship with caesarean section}

According to gestational age, $85 \%$ of pregnancies were in a term, and there weren 't differences between the groups. The main route was vaginal delivery for both cases to controls, no statistically significant difference between the two; there wasn ' $t$ a significant difference between cesarean section in adolescents and young adults (32.8 vs. $36.9 \%$ ) was observed.
ISSN 1794-9831

E-ISSN 2322-7028

Vol. 12 No. 2

Jul - Dic 2015

Cúcuta, Colombia 
ISSN 1794-9831

E-ISSN 2322-7028

Vol. 12 No. 2

Jul - Dic 2015

Cúcuta, Colombia
However, when comparing between different subgroups, according to $\mathrm{WHO}$, it became manifest a statistically significant difference (p 0.01) among adolescents aged 10 to 14 years ended in cesarean section $(43.3 \%)$, comparing them with the rates cesarean of adolescents between 15 and 18 years (32.5\%), and young adults between 19 and 25 years, in whom the caesarean section rate was $39.1 \%$, confirming the results of the bivariate analysis by contrast hypothesis, taking into account age, where it was shown that adolescence is associated with a higher risk of requiring termination of pregnancy by high way (OR 1.3, 95\% CI 1.14 to $1.51, \mathrm{p} 0.000001$ ).

By comparing these data with recent studies are divergences $(5,10,12,18,19)$. For example, the study by Malaberey et al. (18) analyzed a cohort of 6,188,704 cases over a period of 10 years and suggests that adolescents have increased rates of cesarean section, especially those under 12 , in whom the immaturity of the pelvis and is the disproportion cephalopelvic main indication for termination of pregnancy by high way, which has been shown in other studies $(12,20)$.

In the study by Torvie et al. (19), where more than 26,000 women were included, the results of labor compared and childbirth among adolescents and adults, showing that both adolescents between 11 and 14 years, as 15 to 19 years had a decreased risk caesarean section and instrumental delivery compared with young adults between 20 and 24 years; Similar data were obtained in other studies $(3,21-24)$.

These findings have been associated with the best myometrial function in young patients, who are believed to have greater elasticity of connective tissue, which leads to a greater tendency to have normal vaginal deliveries.

Also, given the changes that occur early in the pelvic girdle with the onset of puberty, adolescents can achieve conception and birth successfully, similar to those of adults (5) features. Another reason that can explain this behavior is the association described in the literature, with low birth weight, which means that adolescents have a lower risk of requiring cesarean cephalopelvic disproportion $(10,25)$.

The national picture shows similar findings, as evidenced by the study by Monterrosa (5), made between 1993 and 2005 in a maternity hospital of Cartagena, where it was concluded that although birth rates are increased in the adolescent population , maternal age itself is not an indicator for cesarean section factor, and notes that are obstetrical standards in relation to the maternal pelvis and fetal presentation which condition the behavior that must be followed for proper delivery care in this population group.

In the present study, although there was no significant difference in caesarean section rates among adolescents and young adults, itself a greater tendency and an increase in the risk of making this intervention, especially in younger patients was determined (children under 14 years) who presented a greater proportion alteration in the progression of delivery job in the expansion and / or decrease (13.8\%) or cephalopelvic disproportion (11.5\%). (OR $1.3,95 \%$ CI 1.14 to $1.51, \mathrm{p} 0.000001)$.

These data are corroborated in the literature $(12,20)$, which shows that lower maternal age (especially those under 14 years) and pelvic immaturity present, increases significantly the risk of cephalopelvic disproportion, obstruction labor, arrest of descent increased presence of perineal tears or fistulas, and therefore the need for cesarean section in greater proportion in the population.

\section{Teenage pregnancy and neonatal outcomes}

With regard to the effects of maternal age in different neonatal variables, the results show that there was a low frequency of preterm birth in general $(12.3 \%$ vs. adult adolescents $12.5 \%$ ), and no association was found between adolescent maternal age and an increased risk of low Apgar scores a minute or 5 minutes, similar to results obtained in other studies $(21,24)$. However, when performing the bivariate analysis through hypothesis testing, it was shown that although the birth weight of the children of adolescent vs. the children of young adults $(2,904 \mathrm{~g}$ vs. $2,919 \mathrm{~g})$ are similar, the teen age itself is associated with an increased risk of low birth weight (OR 9.4, 95\% CI 7.59 to 11.76$)$, as described in several studies $(19,22$, 24-26).

Similarly, it is considered that maternal age teenager should be estimated as a predictor for low birth weight, as well as a risk factor for stunting and lower values of head circumference, as described by Chen et al. 
(24) with statistically significant results ( $\mathrm{p}<0.001)$. It is presumed that this involvement and impact on children of adolescents is related to various factors affecting negatively fetal growth, such as exposure to family stressors, poor prenatal care, difficulties in access to health systems, deprivation socio-economic and nutrition, and increased exposure to substances such as tobacco and / or recreational drugs (27-28).

The strengths of this study lie in the large population size, analysis of sociodemographic variables, and the correlation between maternal age and neonatal and obstetrical outcomes. However, it has weaknesses regarding the retrospective nature of the study, implementation and organization databases, it can be generated errors or omissions in the recording and analysis of information, and evaluation of maternal age into subgroups, because although this classification allows easier data interpretation, age should be taken as a continuous variable to prevent the loss of information in cutoffs and more accurate results.

In the future, we may consider whether the teens of the institution studied are affected or are at risk for other complications have been described in the literature, such as anemia, perineal laceration, postpartum hemorrhage, hypertensive disorders or perinatal death (29-30).

\section{CONCLUSIONS}

Teen pregnancy should be considered a public health problem, which impacts negatively on the health of the mother-son, and in the psychosocial field of adolescent women, as it implies limitations on academic economic, labor and exposing mothers and their children to major complications.

Adolescents studied, mostly have secondary basic education $(44.9 \%)$ or are finishing their academic secondary education (39.3\%); $85.5 \%$ of them attended more than four prenatal visits and $85 \%$ of cases had pregnancies to term, with low rates of preterm delivery $(12.3 \%)$ and preterm end $(0.38 \%)$; this shows that the population served by the institution has an average educational level and adequate access to different resources of the health system, hence reducing adverse events and complications, and increases their opportunities for improvement, promotion and prevention.
Analyzing the association between maternal age and cesarean section in different age subgroups, there was not statistically significant difference was found between them; however, it was determined that if there is an increased risk for the realization of this intervention in under 14 years (OR 1.3, 95\% CI 1.14 to $1.51, \mathrm{p} 0.000001$.

Patients under 14 years old have an increased risk of requiring cesarean section (OR 1.3, 95\% CI 1.14 to $1.51, \mathrm{p} 0.000001$ ), probably pelvic immaturity; however, older teenagers, with adequate prenatal care, have a similar young adult behavior, which, although there are no clear indications for cesarean section in adolescents, this behavior should not be performed routinely, and dice the risks must be individualized according to the needs of each patient.

Regarding the association between maternal age and neonatal outcomes, we not found that maternal age adversely affects aspects such as size at birth, prematurity and neonatal Apgar values minute or five minutes. On the other hand, the results showed that maternal adolescence is associated with an increased risk of low birth weight (OR 9.4, 95\% CI 7.59 to 11.76) with statistically significant results.

\section{CONFLICTS OF INTEREST}

The authors declare that there is not conflict of interest.
ISSN 1794-9831

E-ISSN 2322-7028

Vol. 12 No. 2

Jul - Dic 2015

Cúcuta, Colombia 


\section{BIBLIOGRAPHIC REFERENCES}

1. World Health Organization and Department of Reproductive Health and Research, Department of Child and Adolescent Health and Development. Adolescent Pregnancy Issues in Adolescent Health and Development. [Internet]. Geneva: WHO; 2010. [cited 10 December 2015]. Available from: http://apps.who.int/iris/ bitstream/10665/42903/1/9241591455_eng.pdf

2. Geist RR. Teenage Pregnancies Perinatal Outcomes of in a Selected Group of Patients. Department of Obstetrics and Gynecology, Shaare Zedek Medical Center, Jerusalem, Israel and Ben Gurion Hospital of the Negev, Beersheva, Israel. Journal Pediatric Adolescent Gynecology, 2006; 19: 18-193.

3. Zeck W. Adolescent primiparous: Changes in obstetrical risk Between 1983-1987 and 1999-2005. Journal of Obstetrics and Gynecology, 2008; 34 (2): 195-198.

4. Brahmbhatt H, Kagesten A, Emerson M, Decker M, Olumide A, Ojengbede O, et al. Prevalence and Determinants of Adolescent Pregnancy in Disadvantaged Urban Settings Across Five Cities. Society for Adolescent Health and Medicine. Journal of Adolescent Health 2014; 55: S48-S57.

5. Monterrosa-Castro A. Partos vaginales y cesáreas en adolescentes: comportamiento entre 1993 y 2005 . Hospital de Maternidad Rafael Calvo, Cartagena-Colombia. Revista Colombiana de Ginecología y Obstetricia, 2007; 5882: 108-115.

6. The American College of Obstetricians and Gynecologists. Adolescent facts pregnancy, birth and SDT's sexual disease transmission. Women's Health Physicians. [Internet]. Washington, DC. 2009 [cited 10 December 2015]. Available from: http://www.acog.org/-/media/Department-Publications/AdolescentFactsPregnancyAndSTDs. pdf

7. Mangiaterra V, Pendse R, K McClure, J. Rosen Adolescent Pregnancy. Department of Making Pregnancy Safer, World Health Organization - MPS Notes. Vol 1, No. 1. [Internet]. October 2008 [cited 10 December 2015]. Available from: http://www.who.int/maternal_child_adolescent/documents/mpsnnotes_2_lr.pdf

8. Profamilia. Encuesta Nacional de demografía y salud. ENDS 2010. [Internet]. Colombia: Profamilia; 2010 [cited 10 December 2015]. Available from: http://www.profamilia.org.co/encuestas/Profamilia/Profamilia/

9. Morón-Duarte L, C Latorre, Jose Tovar. Risk factors for adolescent pregnancy in Bogotá, Colombia, 2010: a case-control study. Rev Panam Public Health, 2014; 36 (3): 179-184.

10. De Vienne C, Creveuil C, M. Dreyfus young maternal age Does Increase the risk of adverse obstetric, fetal and neonatal outcomes ?: A cohort study. European Journal of Obstetrics \& Gynecology and Reproductive Biology, 2009; 147: 151-156.

11. República de Colombia. Ministerio de Salud. Resolución No. 008430 de 1993, octubre 4. Por la cual se establecen las normas científicas, técnicas y administrativas para la investigación en salud. [Internet]. Bogotá: Ministerio de Salud; 1993 [cited 10 December 2015] Available from: http://www.unisabana.edu.co/fileadmin/Documentos/ Investigacion/comite_de_etica/Res_8430_1993_Salud.pdf

12. Ezegwui HU, Lkeako LC, Ogbuefi F. Obstetric outcome of teenage pregnancies at a tertiary hospital in Enugu, Nigeria. Nigerian Journal of Clinical Practice. Apr-Jun 2012; 15 (2): 147-150.

13. Kawakita T, Wilson K, KL Grantz, Landy HJ, Huang CC, Gomez-Lobo V. Maternal and Neonatal Adverse Outcomes in Adolescent Pregnancy. J Pediatric Adolescent Gynecology, 2015: 1-7. PII: S1083-3188 (15) 003071. doi: 10.1016 / j.jpag.2015.08.006.

14. Gómez-Mercado C, Montoya-Vélez L. Factores sociales, demográficos, familiares y económicos relacionados con el embarazo en adolescentes, área urbana, Briceño. Rev. Salud Pública, 2014; 16 (3): 394-406.

15. Klein JD. Adolescent pregnancy: Current Trends and Issues. Pediatrics [Internet]. 2005 [cited 10 December 2015];116:281. Available from: http://pediatrics.aappublications.org/content/116/1/281

16. Zeteroglu S. Cesarean Delivery Rates in Adolescent Pregnancy. The European Journal of Contraception and Reproductive Health Care 2005; 10 (2): 119-122.

17. Klein D, Gildengorin G, P Mosher, Adelman W. caesarean delivery Adolescent in the US Military health care system. J Pediatr Adolesc Gynecol 2012; 25: 74-76.

18. Malabarey OT, Balayla J, Abenhaim HA. The effect of pelvic size on Cesarean delivery rates: Using an adolescent maternal age as proxy for pelvic unbiased size. J Pediatr Adolesc Gynecol 2012 Jun; 25 (3): 190-4.

19. Torvie AJ, LS Callegari, Schiff MA, Debiec KE. Labor and delivery outcomes Among young adolescents. Am J Obstet Gynecol 2015 Jul; 213 (1): 95.e1-8.

20. Canbaz S, Sunter A. Obstetric outomes of adolescent pregnancies in Turkey. Advances in Therapy, November/ December 2005; 22 (6): 636-41.

21. 
22. Torres-Ramírez A, Coria-Soto IL, Zambrana MM, Lara-Ricalde R. La resolución obstétrica de las adolescentes en comparación con las adultas. Revista de Ginecología y Obstetricia de México 1999; 67 (8): 377-384.

23. Thato 22. S. Obstetric and Perinatal Outcomes of Thai Pregnant Adolescent: A Retrospective Study. Journal of Nursing Studies 2009; 44: 1158-1164.

24. Fleming N. Adolescent Pregnancy Outcomes in the Province of Ontario: A Cohort Study. Journal of Obstetric and Gynaecology Canada 2013: 234-245.

25. Qazi G. Obstetric Characteristics and Complications of Teenage Pregnancy. Journal of Postgraduate Medical Institute 2011; 25: 134-138.

26. Restrepo-Mendez M, Lawlor D, Horta B, Matijasevich A. The association of maternal age and gestational age birthweight with: a cross-cohort comparison. Paediatric and Perinatal Epidemiology 2015; 29: 331-40.

27. Chen YH, Li CR, Lee SH, Hsu BQ, WY Wu, Kuo CP, et al. Growth Changes in infants born of adolescent mothers: results of a national cohort study in Taiwan. J Reprod Med Iran November 2014; 12 (11): 737-746.

28. Pasquialini D, Llorens A. Salud y Bienestar de Adolescentes y Jóvenes: Una Mirada Integral. Buenos Aires: Organización Mundial de la Salud-Organización Panamericana de la Salud; 2010.

29. Fondo de las Naciones Unidas para la Infancia (UNICEF). La Adolescencia, una época de oportunidades. Nueva York: UNICEF; 2011.

30. Hernández M. Mortalidad materna en adolescentes y mortalidad infantil en hijos de madres adolescentes en Nicaragua. Managua: OPS/OMS; 2007.

31. Ramaiya A Kiss L, Baraitser P, Mbaruku G, Hildon Z. A systematic review of risk factors for neonatal mortality in adolescent, mother's in Sub Saharan Africa. BMC Research Notes [Internet]. 2014; 7: 750. [cited 10 December 2015]. Available from: http://www.biomedcentral.com/1756-0500/7/750
ISSN 1794-9831

E-ISSN 2322-7028

Vol. 12 No. 2

Jul - Dic 2015

Cúcuta, Colombia 